\title{
PENGEMBANGAN LABORATORIUM VIRTUAL UNTUK KEGIATAN PRAKTIKUM DAN MEMFASILITASI PENDIDIKAN KARAKTER DI SMK
}

\author{
Hendra Jaya \\ Program studi Pend. Teknik Elektronika \\ FT Universitas Negeri Makassar \\ e-mail : hendramisi@yahoo.com
}

\begin{abstract}
Pengembangan Laboratorium Virtual untuk Kegiatan Praktikum dan Memfasilitasi Pendidikan Karakter di SMK. Tujuan kajian ini adalah untuk mengembangkan laboratorium virtual dalam meningkatkan keterampilan dalam praktik di lab tanpa memerlukan bantuan pendamping dan tidak terikat dengan waktu dan tempat, dan memfasilitasi pendidikan karakter bagi siswa. Virtual laboratory terdiri dari beberapa bagian yaitu: pre-test, post-tests, tugas-tugas, tutorial, simulasi, dan bahan-bahan laboratorium. Learning lab dikembangkan di dalam mata pelajaran produktif dan didukung oleh authoring tools. Virtual labs harus interaktif, dinamik, animatif, tidak membosankan dan didukung oleh keinginan pengguna untuk belajar dan memahami matapelajaran produktif. Laboratorium virtual digunakan untuk meningkatkan kompetensi siswa sekolah kejuruan dalam arti kognitif, psikomotor, dan karakter siswa.
\end{abstract}

Kata Kunci : laboratorium virtual, pendidikan karakter

\section{VIRTUAL LABORATORY DEVELOPMENT FOR PRACTICUM AND FACILITATING CHARACTER EDUCATION IN VOCATIONAL HIGH SCHOOL}

\begin{abstract}
Virtual Laboratory Development for Prakticum and Facilitating Character Edcation in Vocational High School. The purpose of this virtual laboratory is preparing students to improve skills in laboratory practice without the need for escort assistance and are not bound by time and place and facilitate the character education for the student. Virtual laboratory consists of pre-test, posttests,Assignment, tutorials, simulations and lab materials. Learning lab was developed in productive subjects are supported by the software authoring tools. Virtual labs are interactive, dynamic, and animatif, not boring and can to support the user desires to learn and understand course productive material. Virtual laboratory to improve the competence of vocational students in terms of cognitive, psychomotor, and character of the students.
\end{abstract}

Kata Kunci : virtual laboratory, character education

\section{PENDAHULUAN}

Pada saat ini para pendidik sudah mulai mendapatkan akses untuk menggunakan berbagai macam teknologi guna meningkatkan efektifitas proses belajar dan mengajar. Komputer sebagai salah satu produk teknologi dinilai tepat digunakan sebagai alat bantu pengajaran. Berbagai macam pendekatan instruksional yang dikemas dalam bentuk program pengajaran berbantuan komputer atau CAI (Computer-Assisted Instruction) seperti: drill and practice, simulasi, tutorial dan permainan bisa diperoleh lewat komputer.

Simulasi mengenai lingkungan nyata (virtual reality) yang dibuat oleh komputer, dan pengguna dapat berinteraksi dengan hasil yang menampakkan isi dari kenyataan lingkungan disebut kenyataan virtual (Virtual Reality). VR 
merupakan suatu format interaksi manusiakomputer di mana suatu lingkungan nyata atau khayal disimulasikan dan para pemakai dapat berhubungan dan menggerakkan dunia itu. Dalam lingkungan virtual yang paling berhasil, para pemakai merasakan bahwa mereka sungguh hadir di dunia yang disimulasikan dan bahwa pengalaman mereka didalam dunia virtual sebanding dengan apa yang akan mereka alami pada lingkungan sebenarnya.

Virtual Reality dapat diterapkan pada berbagai bidang. Di dalam riset teknik dan ilmiah, laboratorium virtual dapat membantu mengatasi beragai permasalahan di SMK terutama untuk mata pelajaran produktif kejuruan seperti untuk pekerjaan pada peralatan yang berbahaya termasuk diantaranya adalah tegangan yang sangat tinggi atau dengan peralatan mahal lebih baik dilaksanakan melalui simulasi. Untuk mengatasi permasalahan diatas maka perlu upaya untuk mengembangkan sebuah laboratorium virtual di Sekolah Menengah Kejuruan untuk mata pelajaran produktif kejuruan.

Sekolah Menengah Kejuruan (SMK), menurut Undang undang No. 20 tahun 2003 tentang Sistem Pendidikan Nasional didefinisikan bahwa : pendidikan kejuruan merupakan pendidikan yang mempersiapkan peserta didik untuk dapat bekerja dalam bidang tertentu. Lebih spesifik dijelaskan dalam Peraturan Pemerintah No. 19 tahun 2005 tentang Standar Pendidikan Nasional yang menyebutkan target Pendidikan Menengah yaitu : Pendidikan Menengah Kejuruan adalah pendidikan pada pendidikan jenjang menengah yang mengutamakan pengembangan kemampuan siswa untuk jenis pekerjaan tertentu, karenanya pendidikan kejuruan harus dekat dengan dunia kerja.

Lebih jauh dijelaskan dalam Peraturan Pemerintah nomor 19 tahun 2005 tentang Standar Pendidikan Nasional, tujuan penyelenggaraan SMK adalah bahwa "Pendidikan Menengah Kejuruan mengutamakan penyiapan siswa untuk memasuki lapangan kerja mengembangkan sikap profesional". Jika merujuk pada surat Keputusan Mendikbud nomor 0490/U/1990, tujuan pendidikan SMK dapat diuraikan sebagai berikut :

a. Mempersiapkan siswa untuk melanjutkan ke jenjang pendidikan yang lebih dan atau meluaskan pendidikan dasar;

b. Meningkatkan kemampuan siswa sebagai anggota masyarakat dalam mengadakan hubungan timbal baik dengan lingkungan sosial, budaya dan sekitar;

c. Menigkatkan kemampuan siswa untuk dapat mengembangkan diri sejalan dengan pengembangan ilmu, teknologi dan kesenian;

d. Menyiapkan siswa untuk memasuki lapangan kerja dan mengembangkan sikap professional;

Pendidikan kejuruan memiliki karakteristik yang berbeda dengan satuan pendidikan lainnya. Perbedaan tersebut dapat dikaji dari tujuan pendidikan, substansi pelajaran, tuntutan pendidikan dan lulusannya. Pendidikan kejuruan bertujuan untuk meningkatkan kecerdasan, pengetahuan, kepribadian, akhlak mulia, serta keterampilan peserta didik untuk hidup mandiri dan mengikuti pendidikan lebih lanjut sesuai dengan program kejuruannya. Dari tujuan pendidikan kejuruan tersebut mengandung makna bahwa pendidikan kejuruan di samping 
menyiapkan tenaga kerja yang profesional juga mempersiapkan peserta didik untuk dapat melanjutkan pendidikan ke jenjang yang lebih tinggi sesuai dengan program kejuruan atau bidang keahlian.

\section{E-learning}

Dong (2002) mendefinisikan e-learning sebagai kegiatan belajar asynchronous melalui perangkat elektronik komputer yang memperoleh bahan belajar yang sesuai dengan kebutuhannya. Definisi lain (Soekartawi, Haryono dan Librero, 2002): e-Learning is a generic term for all technologically supported learning using an array of teaching and learning tools as phone bridging, audio and videotapes, teleconferencing, satellite transmissions, and the more recognized web-based training or computer aided instruction also commonly referred to as online courses.

Rosenberg (2001) menekankan bahwa elearning merujuk pada penggunaan teknologi internet untuk mengirimkan serangkaian solusi yang dapat meningkatkan pengetahuan dan keterampilan. Onno W. Purbo (2002) menjelaskan bahwa istilah "e" atau singkatan dari elektronik dalam e-learning digunakan sebagai istilah untuk segala teknologi yang digunakan untuk mendukung usaha-usaha pengajaran lewat teknologi elektronik internet.

Cisco (2001) menjelaskan filosofis elearning sebagai: Pertama, elearning merupakan penyampaian informasi, komunikasi, pendidikan, pelatihan secara on-line. Kedua, elearning menyediakan seperangkat alat yang dapat memperkaya nilai belajar secara konvensional (model belajar konvensional, kajian terhadap buku teks, CD-ROM, dan pelatihan berbasis komputer) sehingga dapat menjawab tantangan perkembangan globalisasi. Ketiga, e-learning tidak berarti menggantikan model belajar konvensional di dalam kelas, tetapi memperkuat model belajar tersebut melalui pengayaan content dan pengembangan teknologi pendidikan. Keempat, Kapasitas siswa amat bervariasi tergantung pada bentuk isi dan cara penyampaiannya. Makin baik keselarasan antar conten dan alat penyampai dengan gaya belajar, maka akan lebih baik kapasitas siswa yang pada gilirannya akan memberi hasil yang lebih baik. Sedangkan Karakteristik e-learning, antara lain. Pertama, Memanfaatkan jasa teknologi elektronik; di mana guru dan siswa, siswa dan sesama siswa atau guru dan sesama guru dapat berkomunikasi dengan relatif mudah dengan tanpa dibatasi oleh hal-hal yang protokoler. Kedua, Memanfaatkan keunggulan komputer (digital media dan computer networks). Ketga, Menggunakan bahan ajar bersifat mandiri (self learning materials) disimpan di komputer sehingga dapat diakses oleh guru dan siswa kapan saja dan di mana saja bila yang bersangkutan memerlukannya. Keempat, Memanfaatkan jadwal pembelajaran, kurikulum, hasil kemajuan belajar dan hal-hal yang berkaitan dengan administrasi pendidikan dapat dilihat setiap saat di komputer. Untuk dapat menghasilkan e-learning yang menarik dan diminati.

Onno W. Purbo (2002) mensyaratkan tiga hal yang wajib dipenuhi dalam merancang elearning, yaitu : sederhana, personal, dan cepat. Sistem yang sederhana akan memudahkan peserta didik dalam memanfaatkan teknologi dan menu yang ada, dengan kemudahan pada panel yang disediakan, akan mengurangi pengenalan sistem e-learning itu sendiri, 
sehingga waktu belajar peserta dapat diefisienkan untuk proses belajar itu sendiri dan bukan pada belajar menggunakan sistem elearning-nya.

\section{Laboratorium virtual}

Laboratorium biasanya didefinisikan sebagai: (1) tempat yang dilengkapi untuk eksperimental studi dalam ilmu pengetahuan atau untuk pengujian dan analisa; tempat memberikan kesempatan untuk bereksperimen, pengamatan, atau praktek dalam bidang studi, atau (2) periode akademis disisihkan untuk laboratorium bekerja.

Sebuah laboratorium virtual didefinisikan sebagai lingkungan yang interaktif untuk menciptakan dan melakukan eksperimen simulasi: taman bermain untuk bereksperimen. Ini terdiri dari domain dependent program simulasi, unit eksperimental disebut objek yang mencakup file data, alat yang beroperasi pada benda-benda, dan buku referensi (Mihaela M., 2003)

Laboratorium virtual merupakan sistem yang dapat digunakan untuk mendukung sistem praktikum yang berjalan secara konvensional. laboratorium virtualini biasa disebut dengan Virtual Laboratory atau V-Lab. Diharapkan dengan adanya laboratorium virtual ini dapat memberikan kesempatan kepada siswa khususnya untuk melakukan praktikum baik melalui atau tanpa akses internet sehingga siswa tersebut tidak perlu hadir untuk mengikuti praktikum di ruang laboratorium. Hal ini menjadi pembelajaran efektif karena siswa dapat belajar sendiri secara aktif tanpa bantuan instruktur ataupun asisten seperti sistem yang berjalan. Dengan format tampilan berbasis web cukup membantu siswa untuk dapat mengikuti praktikum secara mandiri (Puspita, 2008).

\section{Laboratorium Virtual untuk Mendukung Kegiatan Belajar-mengajar}

Lingkungan virtual, bernama laboratorium virtual, bervariasi dari halaman web statis dengan video dan teks hingga ke halaman yang dinamis dengan lingkungan canggih, kolaboratif authoring (Emigh \& Herring, 2005), video on demand, pertemuan virtual, dan banyak fitur lainnya. Laboratorium virtual ini juga dapat memungkinkan akses jarak jauh terhadap instrumen pengukuran, kamera video, mikrofon, rangkaian listrik dan mekanik, reaksi kimia, percobaan biologi, dan sebagainya.

Keragaman model dan struktur untuk laboratorium virtual adalah sangat luas dan bervariasi sesuai dengan sifat proyek diteliti, tujuan, dan teknologi yang terlibat. Motivasi untuk implementasi laboratorium virtual termasuk, tetapi tidak terbatas pada:

a. Keterbatasan pada sumber daya dan ruang dalam laboratorium dunia nyata. Jenis keterbatasan dapat menyebabkan keterlambatan dalam kegiatan belajar siswa, yang mungkin menghadapi situasi di mana mereka harus bersaing atau menunggu ketersediaan sumber daya yang diberikan, selain fakta bahwa percobaan seseorang dapat terganggu sebelum menyimpulkan, karena kebutuhan sumber daya terbagi.

b. Kemungkinan berbagi peralatan biasanya mahal.

c. Stimulus untuk kolaborasi penelitian atau bekerja dalam kelompok independen jarak fisik mereka.

d. Keberadaan lingkungan belajar di luar sekolah, yang memungkinkan siswa untuk 
berpartisipasi atau mengembangkan proyek mereka sendiri bersama-sama dengan siswa lain di waktu luang mereka.

e. Kemungkinan mengembangkan berbagai percobaan di lokasi yang berbeda.

f. Pengawasan terpencil dan intervensi dalam eksperimen berbahaya, sehingga membantu untuk mencegah kecelakaan.

\section{Jenis Laboratorium Virtual}

Laboratorium virtual dapat dibedakan menjadi dua tipe utama yaitu laboratorium berdasarkan simulator dan laboratorium yang berbasis pada peralatan hardware yang nyata baik 2-D maupun 3-D. Tipe pertama didasarkan pada set model perangkat lunak yang merupakan objek atau sistem dalam tingkat abstraksi tertentu. Satu-satunya masalah di sini adalah dengan keakuratan perilaku simulator. Sangat sering benda nyata berbeda dari model abstrak mereka. Hal ini karena model abstrak yang dikembangkan menjadi sederhana dan untuk membantu siswa untuk memahami dasar-dasar. Kebanyakan dari mereka tidak dapat mewakili semua fitur dari objek simulasi. Jenis kedua laboratorium virtual yang mencakup sebagian besar kualitas jenis pertama dan memungkinkan pendekatan ini untuk yang klasik. Di setiap kelas terdapat rak-rak dengan peralatan yang tidak dapat digunakan untuk pembelajaran jarak jauh dan tidak dapat diakses bagi para siswa sepanjang waktu. Jadi menggabungkan klasik dengan belajar yang modern memungkinkan akses remote ke peralatan nyata dapat meningkatkan fleksibilitas proses pengajaran dan penggunaan laboratorium nyata. Menggunakan teknologi perangkat lunak dan jaringan menyediakan akses yang terhubung ke peralatan.

\section{Pendidikan Karakter}

Pengembangan karakter anak didik merupakan salah satu pilar dari program Mendiknas saat ini, hal ini juga sangat urgen untuk dikembangkan (Maesuri, 2009). Berkaitan dengan hal tersebut seperti yang dijelaskan oleh Nur (2010:1) bahwa:Karakter merupakan kepribadian yang utuh yang mencerminkan keselarasan dan keharmonisan oleh HATI (Jujur, bertanggung jawab), PIKIR (cerdas), RAGA (sehat dan bersih), serta RASA dan KARSA (peduli dan kreatif). Dengan demikian pendidikan karakter merupakan proses pemberian tuntunan peserta atau anak didik agar menjadi manusia Indonesia seutuhnya yang berkarakter dalam dimensi hati, pikir, raga, serta rasa dan karsa. Peserta didik diharapkan memiliki karakter yang baik meliputi kejujuran, tanggung jawab cerdas, bersih, dan sehat, peduli dan kreatif (Tim Pendidikan Karakter Kementrian Pendidikan Nasional).

Dengan demikian selain mengenalkan, melatihkan, dan membiasakan siswa dengan TIK (Teknologi Informasi dan Komunikasi), maka tidak kalah pentingnya media pembelajaran yang dikembangkan mengandung unsure-unsur pendidikan karakter dan keterampilan sosial termasuk diantaranya aktif mengajukan pertanyaan, aktif memberikan idea tau pendapat, menjadi pendengar yang baik, dan bekerjasama dalam menyelesaikan suatu permasalahan.

Dalam tulisan ini, karakter yang ingin dikembangkan adalah karakter yang dapat dipercaya, menghargai, tanggungjawab individu, tanggung jawab sosial, adil dan peduli. Dengan demikian karakter karakter tersebut mempunyai indikator sebagai berikut: 
1. Dalam proses praktikum, siswa SMK dapat dilatihkan karakter dapat dipercaya (jujur, mengikuti komitmen, mencoba melakukan tugas yang diberikan, menjadi teman baik, dan membantu orang lain)

2. Dalam proses praktikum, siswa dapat dilatihkan karakter menghargai (memperlakukan guru dan teman dengan baik, sopan dan hormat, peka terhadap perasaan orang lain, tidak menghina atau mempermainkan teman/guru)

3. Dalam proses praktikum, siswa dilatihkan karakter tanggungjawab individu. (mengerjakan tugas-tugas yang diberikan, dan dapat dipercaya)
4. Dalam proses praktikum, siswa dapat dilatihkan karakter adil. (tidak menyontek hasil praktek siswa lain, tidak curang)

5. Dalam proses praktikum, siswa dapat dilatihkan karakter peduli. (siswa peka terhadap perasaan orang lain, mencoba untuk membantu siswa lain).

\section{A. Pengembangan Laboratorium Virtual}

Dengan mengadaptasi model penelitian clan pengembangan pendidikan Borg \& Gall. Model pengembangan Instruksional dari Dick \& Carey (2001), dan Model pengembangan Cennamo dan Kalk, diajukan suatu model pengembangan laboratorium virtual dalam penelitian ini sebagai berikut.

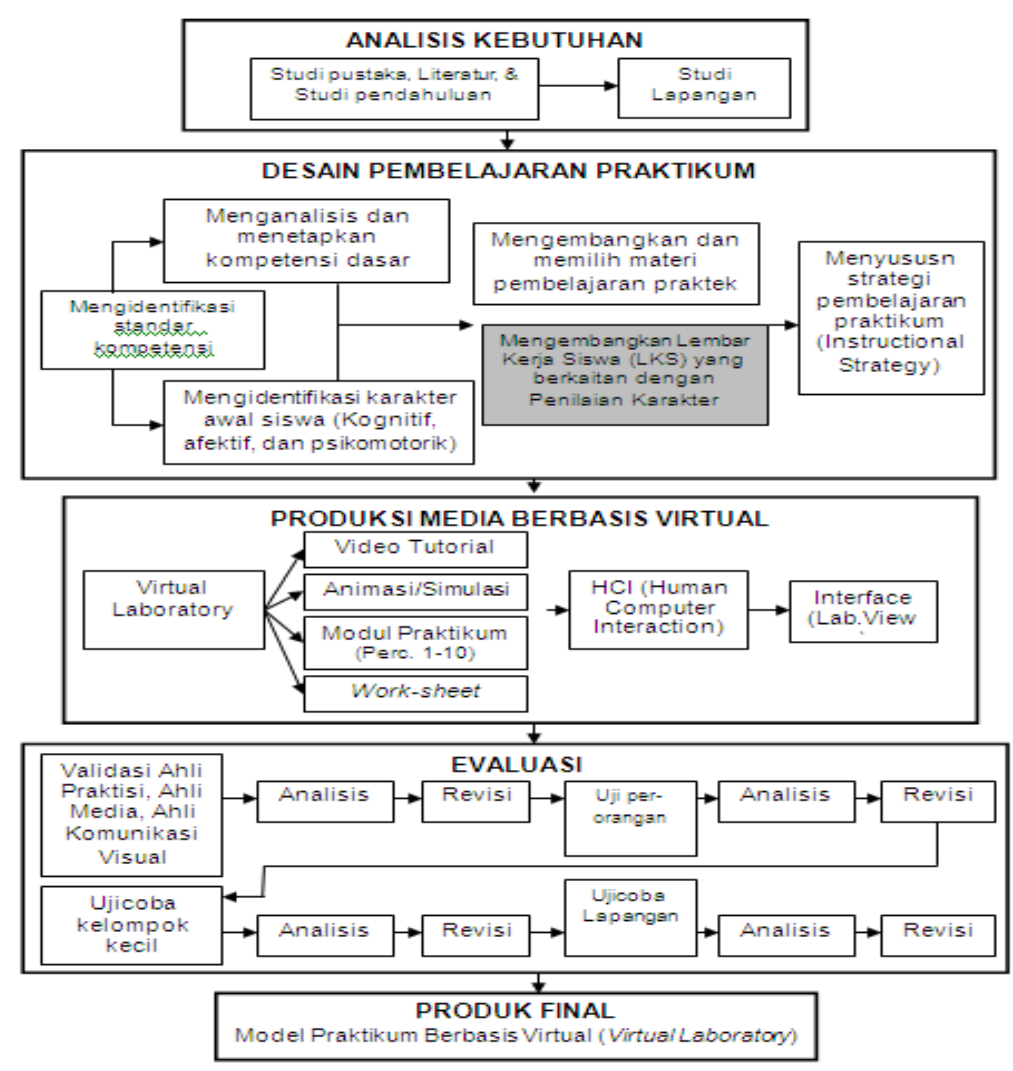

Gambar 1.

\section{PENGEMBANGAN LABORATORIUM VIRTUAL}

Pembelajaran praktikum berbasis virtual yang dikembangkan adalah pada mata pelajaran Elektronika Digital, dimana mata pelajaran ini sebagai mata pelajaran dasar yang digunakan pada jurusan listrik, elektronika dan informatika. Produk yang dkembangkan menggunakan LabView didukung oleh macromedia flash 
untuk simulasi yang dapat mendukung kegiatan praktikum. Hasil pengembangan adalah berupa program komputer dan perancangan sistem.
Untuk perancangan diperlukan langkah-langkah sebagai berikut :

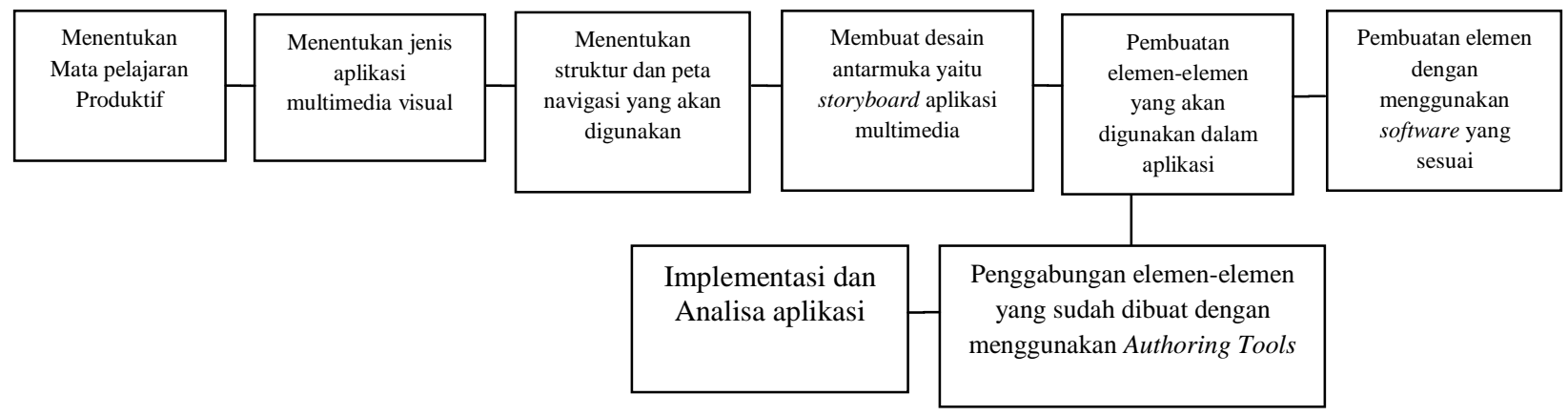

Gambar 2. Langkah Perancangan Sistem

Dalam praktikum elektronika terkadang lingkungan virtual digunakan secara visual untuk menyelidiki apapun yang terjadi pada peristiwa dunia fisik yang sedang dalam pengamatan, terlebih lagi jika aliran arus listrik yang tidak tampak oleh mata maka perlu disimulasikan.

Salah satu indera yang banyak digunakan untuk mendapatkan informasi dari lingkungannya adalah penglihatan. Indera penglihatan digunakan lebih dari indera yang lain dalam memproses informasi. Beberapa penelitian psikologi menunjukkan bahwa lebih banyak informasi dapat dimengerti ketika disajikan dalam bentuk visual, dibandingkan penyajian dalam bentuk non visual.

Pembelajaran berbasis virtual utamanya pada kegiatan praktikum di SMK dapat mengurangi biaya dibandingkan dengan pelatihan bersifat konvensional. Kebutuhan akan peralatan dan bahan praktek yang mahal dalam laboratorium nyata, atau peralatan tambahan untuk kegiatan praktek dapat dikurangi. Keuntungan menggunakan media praktikum berbasis virtual sebagai alat pelatihan adalah; (1) mengurangi waktu praktikum dalam lingkungan yang sebenarnya/nyata, (2) dapat mengadakan praktek dalam kondisi yang berbahaya (tegangan tinggi) dan diperlukan ketelitan konsumsi daya perangkat elektronik (mencegah hubung singkat dan arus berlebih yang dapat mengakibatkan rusaknya perangkat elektronik), (3) lebih menghemat biaya melalui praktikum yang sama, (4) menyediakan akses tak terbatas kepada peralatan yang mahal, (5) menghapuskan biaya bepergian ke pusat praktikum, (6) biaya perbaikan/penggantian komponen dan peralatan elektronik yang mahal dapat dikurangi, dan (7) memungkinkan semua pelajar SMK dapat berkolaborasi, sharingdan bekerjasama baik melalui LAN maupun jaringan Internet seperti ditunjukkan pada Gambar 3 dibawah ini. 


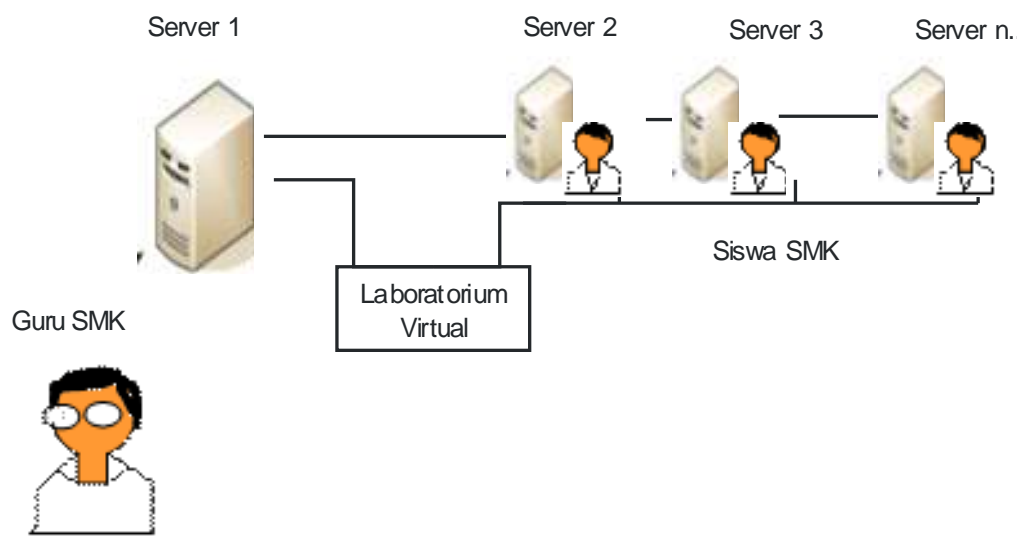

Gambar 3. Kolaborasi Laboratorium Virtual di SMK

\section{Laboratorium Virtual memfasilitasi Pendidikan Karakter Siswa SMK}

Pendidikan kejuruan memiliki karakteristik yang berbeda dengan satuan pendidikan lainnya. Perbedaan tersebut dapat dikaji dari tujuan pendidikan, substansi pelajaran, tuntutan pendidikan dan lulusannya. Pendidikan kejuruan bertujuan untuk meningkatkan kompetensi termasuk diantaranya kecerdasan, pengetahuan (kognitif), kepribadian, akhlak mulia (afektif), serta keterampilan (psikomotorik) sesuai dengan program kejuruannya. Melalui laboratorium virtual ini mampu meningkatkan ketiga aspek tersebut baik kognitif, afektif dan psikomotorik.

Laboratorium virtual dirancang untuk memfasilitasi siswa dalam pengembangan pengembangan perilaku karakter dan keterampilan sosial. Pada bagian rancangan media harus dipikirkan pada bagian mana akan membelajarkan siswa. Termasuk dalam penggunaan warna warna tertentu, aspek karakter warna merah akan berbeda dengan karakter warna biru. Selain proses melatihkan/menumbuhkan karakter harus jelas, maka cara assesement terhadap karakterpun harus jelas. Assesemen ini sangat berguna bagi guru untuk mengetahui perkembngan siswanya dan juga untuk memberikan ide tentang hal lebih apa yang dapat dilakukan untuk membantu anak menjadi insan yang berkarakter. Dengan demikian siswa akan menjadi awaremenyadari pentingnya karakter tersebut, dan akan membantu diri mereka pada pembiasaan pembiasaan, maka terbentuklah karakter pada diri mereka.

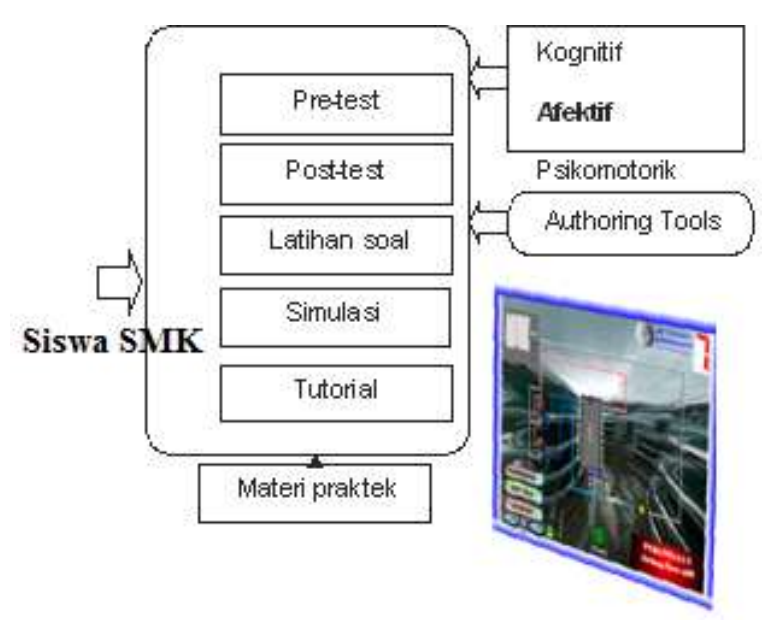

Gambar 4. Pengembangan Laboratorium Virtual untuk Mendukung Kegiatan Praktikum dan Memfasilitasi Pendidikan Karakter Siswa SMK

Pengembangan laboratorium virtual berfokus kepada: 1) pengembangan konten pembelajaran praktikum, 2) peningkatan hasi belajar siswa SMK yang diperoleh dan dan dapat di ukur, 3) strategi pemberian konten mata praktek, 4) evaluasi kemampuan siswa SMK dengan baik, 5) kemampuan siswa SMK dalam menyalurkan 
dan mengaplikasikan pengetahuan melalui laboratorium virtual, 6) kemampuan siswa SMK dalam mengakses berbagai pertanyaan yang bervariasi, dan 7) kemampuan dalam menggunakan topik yang akan diaplikasikan kedalam kerja praktek di industri.

\section{Laboratorium Virtual Memfasilitasi Siswa SMK Berfikir Kritis}

Praktikum pada mata peajaran Elektronika Digital terdiri dari beberapa modul. Setiap modul memfasilitasi siswa untuk melakukan simulasi rangkaian. Setelah siswa telah menyelesaikan rangkaian yang telah dibuat siswa ditantang untuk melakukan eksplorasi apakah rangkaian yang telah dibuat berhasil atau gagal selanjutnya menganalisa kegagalan dan keberhasilan.

\section{Virtual Hands-on dan Hands-on Activity}

Proses praktikum melalui laboratorium virtual yang dikembangkan dan di desain dapat memfasilitasi siswa untuk berfikir dan melibatkan siswa secara aktif dalam virtual hands-on menggantikan peralatan yang sebenarnya melalui simulasi dengan karakter dan penampakan lingkungan virtual (mirip peralatan nyata). Selanjutnya latihan soal yang dikembangkan dilengkapi dengan hands-on activity.

\section{PENUTUP}

\section{A. Kesimpulan}

1. Laboratorium virtual dapat mendukung kegiatan praktikum di laboratorium yang bersifat interaktif, dinamis, animatif, dan berlingkungan virtual sehingga tidak membosankan dan dapat mendukung keinginan pengguna untuk mempelajari dan memahami materi pelajaran produktif di SMK.

2. Laboratorium virtual dapat meningkatkan kompetensi siswa SMK dari segi kognitif (minds-on), dan psikomotorik.

3. Laboratorium virtual dapat memfasilitasi pendidikan karakter siswa SMK.

\section{B. Saran}

1. Laboratorium virtual dapat digunakan untuk mendukung Pola belajar jarak jauh, namun untuk itu perlu dikembangkan lebih jauhlagi. Disamping perkayaan materi belajar maupun penambahan web engine.

2. Mahasiswa perlu lebih dimasyarakatkan dengan penggunaan komputer untuk belajar secara interaktif dengan CAI.

3. Pemahaman terhadap suatu ilmu tidak cukup hanya melalui teori. Perlu adanya kegiatan lab atau praktikum untuk meningkatkan pemahaman siswa terhadap materi. Pemilihan sarana untuk membantu praktikum perlu dipertibangkan dari segi efisiensi dan biaya. Laboratorium Virtual merupakan pilihan yang tepat untuk mempermudah praktikum Sistem Operasi.

\section{DAFTAR PUSTAKA}

Depdiknas. (2002). Pendekatan Kontekstual (Contekstual Teaching Learning/CTL). Jakarta: Depdiknas

Dick, Walker \& Carey. Lou, Carey., James O. (2001). The systematic design of Instruction $\left(5^{\text {th }} E d\right)$. New York. Longman

Gagne, R, M. \& Briggs L.J. (1974). Principle of Instructional Design. New york: Holt, Rinehart \& Winston.

Gall, D. Meredith., Borg., Walter R.(2003). Education Research : an Introduction. $\left(7^{\text {th }}\right.$ Edition). Allyn and Bacon.

Haigh, W. (1993). Using Computer to Solve Problems by The Guess and Test Method. 
School Science and Mathematics, 93(2), $92-95$

Hartoyo.(1999). Kemampuan Mengajar Praktik Guru Sekolah Menengah Kejuruan Negeri (SMKN) Jurusan Listrik di Kota Madya Yogyakarta. Tesis Magister, Universitas Negeri Yogyakarta, Yogyakarta.

Heri Kurniawan. (2009). Pengajaran Konsep Sistem Operasi Dengan Memanfaatkan Perangkat Lunak Mesin Virtual Dan Minix. Jurnal ISSN: 1907-5022. SNATI. Yogyakarta

Iriany. ___ Model pembelajaran inkuiri laboratorium berbasis teknologi informasi pada konsep laju Reaksi Untuk Meningkatkan Keterampilan Berfikir Kreatif Siswa SMU. Bandung: UPI

Jaya Kumar C. Koran, Aplikasi 'E-Learning' Dalam Pengajaran Dan Pembelajaran Di Sekolah-Sekolah Malaysia: Cadangan Perlaksanaan Pada Senario Masa Kini, Pasukan Projek Rintis Sekolah Bestari Bahagian Teknologi Pendidikan, Kementerian Pendidikan Malaysia.

Kozma, R.B, Belle, L.W \& Williams, G.W. (1978). Instructional Techniques in Higher Education. Englewood Cliffts, N.J. Educational Technology Publication

Kristian Ismail. (2010). Perencanaan Virtual Lab untuk Layanan E-learning di Daerah Pedesaan. TELIMEK - Lembaga Ilmu Pengetahuan Indonesia,STEI - Institute Teknologi Bandung

Muhibbin Syah. (2002). Psikologi Pendidikan dengan Pendekatan Baru. Bandung : Rosda karya

M. Iqbal Arsyad. (2004). Pengaruh Animasi pada Program Instruksional Pendidikan. Makalah: Seminar Nasional Aplikasi Teknologi Informasi (SNATI). Yogyakarta.

Nana Sudjana, dan Ahmad Rivai.(2001). Media Pengajaran. Jakarta : Sinar Baru Algesindo.

Nurhadi dkk. (2003). Pembelajaran Kontekstual (CTL) dan Penerapannya dalam KBK. Malang: Universitas Negeri Malang.

Nurrosat, Muchamad azwar. (2009). Penerapan Joomla Dan Moodle Pada Sistem Virtual Laboratorium Online PSD III Teknik Elektro. Laporan tugas akhir. Program studi DIPLOMA III Teknik Elektro
Fakultas Teknik. Universitas Diponegoro, Semarang.

Orlich, D.C, et.al.(2007). Teaching Strategies: A guide to Effective Instruction. New York: Houghton Mifflin Company.

Onno W. Purbo \& Antonius Aditya Hartanto. (2002). Teknologi E-learning Berbasis PHP dan MySQL, Elex Media Komputindo.

Oos M. Anwas, (2003). Model Inovasi ELearning Dalam Meningkatkan Mutu Pendidikan, Jurnal Teknodik, Edisi No.12/VII/Oktober/2003.

Puspita, Rani. (2008). Sistem Informasi Aplikasi Virtual Lab Pada Laboratorium Sistem Informasi Universitas Gunadarma. Proceeding, Seminar Ilmiah Nasional Komputer dan Sistem Intelijen (KOMMIT 2008) Auditorium Universitas Gunadarma, Depok, 20-21 Agustus 2008. ISSN : 1411-6286.

Pintrich, P. R., \& De Groot, E. (1991). Motivational And Self-Regulated Learning Components of Classroom Academic Performance. Journal Of Educational Psychology

Sarifuddin Madenda \& Tommy F.R. (2008). Visualisasi Aktivitas Sistem Organ Tubuh Berbasis Web Dan Multimedia : Aplikasi E-Learning. Universitas Gunadarma. Jakarta.

Sege, Djafar. (2005). Pengaruh Motivasi, Pembelajaran, dan Fasilitas terhadap kemempuan kerja Las Siswa SMK Muhammadiyah 3 Yogyakarta. Tesis Magister, Universitas Negeri Yogyakarta, Yogyakarta.

Soekartawi, (2003). Prinsip Dasar E-Learning: Teori Dan Aplikasinya Di Indonesia, Jurnal Teknodik, Edisi No.12/VII/Oktober/2003.

Suharsimi, Arikunto. (1988). Organisasi dan Administrasi Pendidikan Teknologi dan Kejuruan. Jakarta : Departemen Pendidikan dan Kebudayaan. Direktorat Jendral Pendidikan Tinggi.

Tasma Sucita. 2009. Pengembangan Model Pembelajaran Praktikum Berbasis Software Komputer. Jurusan Pendidikan Teknik Elektro - Universitas Pendidikan Indonesia

Metode Simple Additive Weighting (Saw). 